Kalpa Publications in Civil Engineering
Volume 1, 2017, Pages 343-351
ICRISET2017. International Conference on Re-
search and Innovations in Science, Engineering
\&Technology. Selected papers in Civil Engineering $\quad$ Ka L po

\title{
Groundwater Quality Assessment for Irrigation Water Use in Mahi Right Bank Command Area, Gujarat, India
}

\author{
Prof. (Mrs) Reshma L. Patel ${ }^{1}$, Dr. S. D. Dhiman ${ }^{2}$ \\ ${ }^{1}$ Associate Professor, Civil Engineering Department, B.V.M.Engineering College, Vallabh \\ Vidyanagar, Gujarat, India \\ rlpatel@bvmengineering.ac.in \\ ${ }^{2}$ Associate Professor, Civil Engineering Department, B.V.M. Engineering College, Vallabh \\ Vidyanagar, Gujarat, India \\ sddhiman@bvmengineering.ac.in
}

\begin{abstract}
Hydrochemical study was carried out in Mahi Right Bank Command Area in Central Gujarat, India to understand suitability of groundwater quality for irrigation purpose. Groundwater quality data for shallow wells were collected from State water data centre and Gujarat Engineering Research Institute. $\mathrm{Na}-\mathrm{Cl}, \mathrm{Na}-\mathrm{HCO} 3-\mathrm{Cl}, \mathrm{Ca}-\mathrm{Na}-\mathrm{HCO} 3-\mathrm{Cl}, \mathrm{Ca}-$ $\mathrm{Na}-\mathrm{Cl}$ are dominant groundwater type. Quality assessment for groundwater in the study area was carried out for irrigation purpose on basis of salinity index, SAR, \% Sodium, RSC (Residual Sodium Carbonate), PI (Permeability Index), MH (Magnesium Hazard), and USDA (United States Department of Agricultural) Classification. It is observed that except few locations most of the groundwater samples were not suitable for irrigation based on $\mathrm{MH}$. The groundwater quality assessment carried out will help the irrigation engineers and the other stake holders in planning the conjunctive water use for agricultural activities in the command area.
\end{abstract}

Keywords- Irrigation Water Quality, Sodium Adsorption Ratio (SAR), Magnesium Hazard (MH)

C.D. Modhera, G.J. Joshi, D. Soni, I.N. Patel, A.K. Verma, L.B. Zala, S.D. Dhiman, D.R. Bhatt, J.M. Rathod, B.C. Goradiya, M.S. Holia and D.K. Patel (eds.), ICRISET2017 (Kalpa Publications in Civil Engineering, vol. 1), pp. 343-351 


\section{Introduction}

Agriculture is one of the most important sector in the Indian economy. Rising stress on natural resources in different parts of our country is observed because of intensive agriculture. The major environmental issues related with intensive agriculture include deterioration and over exploitation of groundwater quality, decline in quality of soils because of excessive use of synthetic (chemical) fertilizers, health hazards caused because of use of variety of pesticides, decline in crop diversity, nutrient deficiencies, salinity and waterlogging. Reliable and economic potable water supply is assured by Groundwater resource and it meets the industrial and irrigation water demands in many countries. Groundwater contamination problems in India are mainly due to salinity, arsenic, fluoride, and nitrate. Groundwater chemistry in an area is influenced by several processes like rock/soil-water interaction during recharge and groundwater flow, precipitation/dissolution of mineral species, prolonged storage in the aquifer, exchange, and adsorption/desorption gas exsolution/dissolution (Hem 1985). Recent studies also show that land use and urbanisation also causes impact on the hydrochemistry and hence there is a need for assessment and effective management of groundwater resources (Jeong, 2001). It is observed from water quality surveys that farmers of semi-arid and arid regions continue to use water which otherwise be treated as unsuitable on the criteria set by various scientific institutions. Hence the need arises to evaluate the groundwater pollution potential of the aquifers, in irrigation areas.

\section{Study Area}

The Mahi Right Bank Command Area (MRBC) is agricultural dominant area with few major industries (Fig.1). The study area covers three southern talukas of Kheda District i.e. Nadiad, Thasara, and Matar, and entire Anand district and in Gujarat state between latitudes $22^{\circ} 14^{\prime}$ and $22^{\circ} 53^{\prime}$ North and longitudes $72^{\circ} 25^{\prime}$ and $73^{\circ} 25^{\prime}$ East of Greenwich. The area extends nearly 70 miles in Northeast to Southwest and 11 miles on average from north to south and measures a total of 1335 sq.miles. $\left(2997 \mathrm{Km}^{2}\right)$. The study area is bounded by the river Shedhi on the north direction, on East direction by Mahi river, on the west direction by Sabarmati and Watrak rivers and towards the south direction by gulf of Khambhat. The land in the study area is having almost monotonous and flat topography with a gentle slope from the northeast to the southwest. All the rivers in the study area is having south westerly flows and are perennial. The main Kharif crops in the command area are paddy, jawar, bajara, pulses, potato, tobacco, castor bean and vegetables.

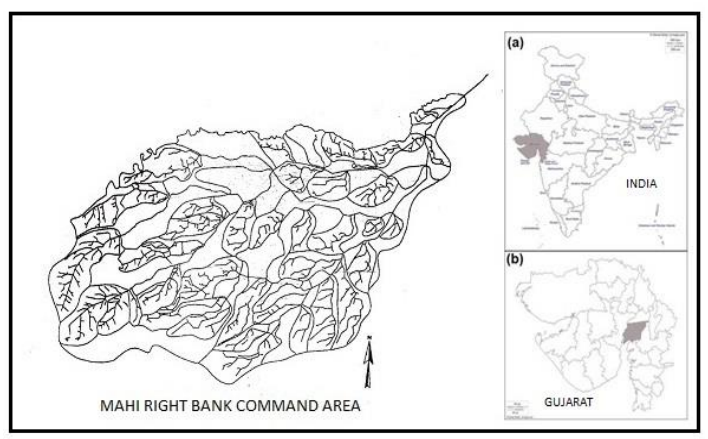

Figure 1: Location Map of the study (MRBC) area 


\subsection{Climate and Rainfall}

There are three main seasons in the project area. The monsoon between mid-June to mid-October, with average rainfall of about $823 \mathrm{~mm}$, temperature declines to $35^{\circ} \mathrm{C}$, humidity rises to $95 \%$ and evaporation is low. The fair weather season extends from mid-October to February where rainfall is less, temperatures are moderate and evaporation is higher. The hot weather season which lasts from March to mid-June where rains are scanty, temperature reaches to $44^{\circ} \mathrm{C}$ and evaporation is highest.

\subsection{Hydrogeology}

The top layer of the MRBC aquifer consists of the recent to sub recent alluvium related to the sediments brought by the rivers Mahi, Shedhi, Vatrak and Sabarmati. The thicknesses of alluvial deposits are estimated to vary between 30 to $150 \mathrm{~m}$ from east to south west. The alluvium consist of silt, clay, sand and pebbles in various proportions. The underneath rock is of Gaj Deccan trap and Godwana formation such as limestone, clays, basalt, dolerite, coarse sand stone, grit, conglomerate and shales. MRBC command area lies in the Cambay geo-hydrological basin.

\section{Materials and Method}

Groundwater quality data for 109 shallow wells were collected from State Water Data Centre of GWRDC (Gujarat Water Resources Development Corporation), Ahmedabad and GERI (Gujarat Engineering Research Institute), Vadodara, For premonsoon (May/June) and postmonsoon season (Oct/Nov) for the calendar year 2007 and few data for some wells are for calendar year 2006. Data for various groundwater quality parameter are available for major cations $\mathrm{Na}^{+}, \mathrm{K}^{+,} \mathrm{Ca}^{+2}, \mathrm{Mg}^{+2}$, and major anions like $\mathrm{SO}_{4}{ }^{-2}, \mathrm{Cl}^{-} \mathrm{HCO}_{3}^{-}, \mathrm{CO}_{3}^{-2}$. For 22 open wells the data for fluoride and nitrate is available for pre-monsoon and post-monsoon season.

Ionic balance error was checked for the analytical precision for the measurements of cations and anions that varies by $1-10 \%$.

Hydro geochemical analysis was carried out to study various mechanisms and process affecting the chemistry of groundwater for irrigation command area for open wells. The quality assessment was made using $\mathrm{pH}$, EC, Total Dissolved solids (TDS), besides major cations $\left(\mathrm{Na}^{+}, \mathrm{K}^{+}, \mathrm{Ca}^{+2}, \mathrm{Mg}^{+2}\right)$ and anions $\left(\mathrm{Cl}^{-}, \mathrm{SO}_{4}^{-2}, \mathrm{CO}^{-2}, \mathrm{HCO}^{-}, \mathrm{NO}_{3}^{-}\right)$. The Nitrate data is available for 22 open wells only. Groundwater suitability for irrigation purpose in this study area was assessed using Salinity Index, \% Na, SAR (Sodium Adsorption Ratio), MH (Magnesium hazard), Permeability Index (PI), RSC (Residual Sodium carbonate), and USDA (United States Department of Agriculture) classification.

\section{Results and Discussion}

The summary of the concentration of groundwater quality parameters for premonsoon and postmonsoon season in the study area is represented in Table 1. Groundwater of the study are alkaline, with a $\mathrm{pH}$ ranging between 7.6 and 9.3 showing an average value of 8.47 in pre-monsoon season. Electrical conductivity ranges from $630 \mu \mathrm{s} / \mathrm{cm}$ to $15700 \mu \mathrm{s} / \mathrm{cm}$ with an average of $4018.7 \mu \mathrm{s} / \mathrm{cm}$ in premonsoon 
season. (Table-1). The dominance of cations in study area observed is $\mathrm{Na}^{+}>\mathrm{Mg}^{+2}>\mathrm{Ca}^{+2}>\mathrm{K}^{+}$and for the anions is $\mathrm{Cl}^{-}>\mathrm{HCO}_{3}>\mathrm{SO}_{4}^{-2}$. Results reveal that there is dominance of evaporation. The general chemical nature of groundwater can be understood by plotting major cation and anion concentration on a piper trilinear diagram (Piper 1944). $\mathrm{Na}-\mathrm{Cl}, \mathrm{Na}-\mathrm{HCO}_{3}-\mathrm{Cl}, \mathrm{Ca}-\mathrm{Na}-\mathrm{HCO}_{3}-\mathrm{Cl}$ are the major water type dominant in this area (Fig 2).

\begin{tabular}{ccccc}
\hline $\begin{array}{c}\text { Groundwater Quality } \\
\text { Parameters }\end{array}$ & Minimum & Maximum & Mean & Standard Deviation \\
\hline $\mathrm{pH}$ & 7.6 & 9.3 & 8.47 & 0.387 \\
$\mathrm{Ca}$ & 6.0 & 170 & 34.0 & 25.75 \\
$\mathrm{Mg}$ & 12.0 & 603.6 & 147.2 & 123.9 \\
$\mathrm{Na}$ & 63.0 & 2799.1 & 583.0 & 546.17 \\
$\mathrm{~K}$ & 1.5 & 351.0 & 48.64 & 55.79 \\
$\mathrm{CO}_{3}$ & 4.3 & 240.0 & 73.74 & 45.2 \\
$\mathrm{HCO}_{3}$ & 91.5 & 3507.5 & 549.5 & 427.95 \\
$\mathrm{Cl}$ & 53.25 & 4615.0 & 920.0 & 1001.38 \\
$\mathrm{SO}$ & 4.8 & 912.0 & 148.3 & 162.26 \\
$\mathrm{EC}$ & 630 & 15700.0 & 4018.7 & 3267.46 \\
$\mathrm{TDS}$ & 420 & 10520.0 & 2689.35 & 2188.75 \\
\hline
\end{tabular}

\begin{tabular}{ccccc}
\hline $\begin{array}{c}\text { Groundwater Quality } \\
\text { Parameters }\end{array}$ & Minimum & Maximum & Mean & Standard Deviation \\
\hline $\mathrm{pH}$ & 7.4 & 9.0 & 8.22 & 0.363 \\
$\mathrm{Ca}$ & 6.0 & 126 & 43.0 & 27.72 \\
$\mathrm{Mg}$ & 6.0 & 552 & 116.47 & 94.86 \\
$\mathrm{Na}$ & 50.0 & 1207.50 & 372.76 & 242.3 \\
$\mathrm{~K}$ & 0.2 & 604.5 & 73.88 & 76.22 \\
$\mathrm{CO}_{3}$ & 4.3 & 150 & 52.44 & 29.03 \\
$\mathrm{HCO}_{3}$ & 152 & 1525 & 486.76 & 245.97 \\
$\mathrm{Cl}$ & 64.0 & 2946.5 & 614.37 & 555.4 \\
$\mathrm{SO}_{4}$ & 24.0 & 648 & 133.55 & 130.85 \\
$\mathrm{EC}$ & 800 & 9400 & 2997.61 & 1878.49 \\
$\mathrm{TDS}$ & 530 & 6300 & 1981.65 & 1238.57 \\
\hline
\end{tabular}

Table 1: Descriptive Statistics for quality parameters of groundwater (all parameters are expressed in $\mathrm{mg} / \mathrm{L}$ except $\mathrm{pH}$ and $\mathrm{EC}$ (in $\mu \mathrm{s} / \mathrm{cm}$ ) in pre-monsoon and post-monsoon season. 

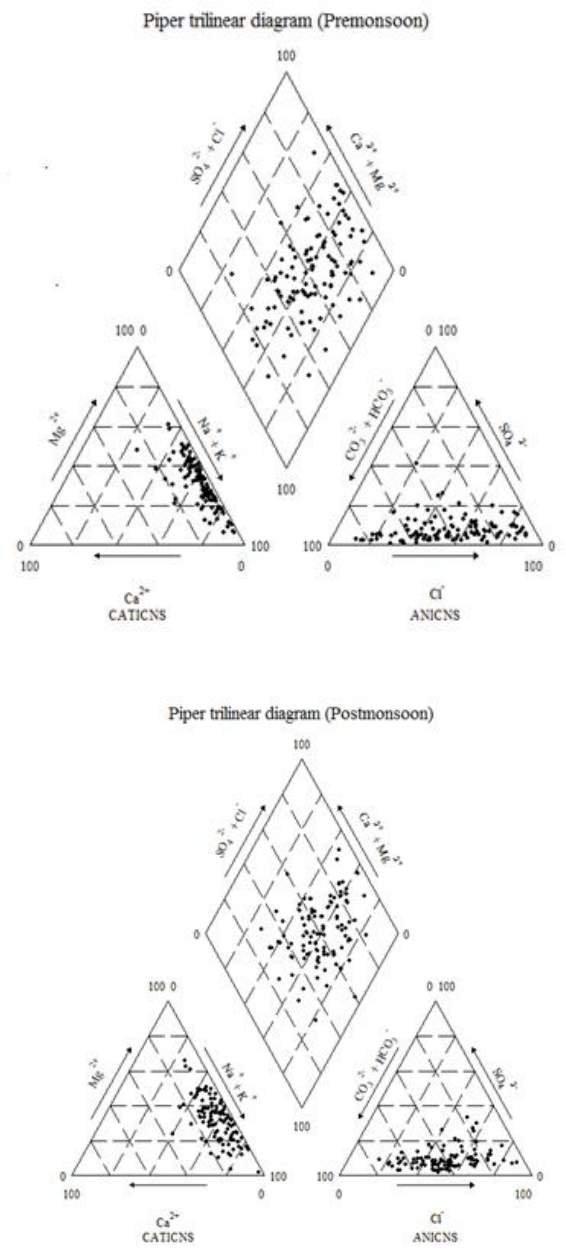

Figure 2: Piper trilinear diagram (premonsoon and postmonsoon)

\subsection{Salinity Index}

Root area and flow of water is affected by groundwater having high EC content. Groundwater in the study area was grouped according to the guideline established by USDA based on EC.

\begin{tabular}{ccccc}
\hline EC $(\mu \mathrm{S} / \mathrm{cm})$ & Salinity Class & \multicolumn{2}{c}{$\%$ of Samples } & Quality Remarks \\
& & Premon Season & Postmon Season & \\
\hline$<250$ & $\mathrm{C} 1$ & Nil & Nil & Excellent \\
$250-750$ & $\mathrm{C} 2$ & 1.8 & Nil & Good \\
$750-2250$ & $\mathrm{C} 3$ & 34.9 & 46.8 & Permissible \\
$2250-5000$ & $\mathrm{C} 4$ & 63.3 & 53.2 & Unsuitable \\
\hline
\end{tabular}

Table 2: Suitability for Irrigation based on United States Department of Agriculture classification

This showed that more than $50 \%$ of groundwater in this area is not suitable for irrigation. 


\subsection{Percent Sodium}

Sodium is an important parameter for irrigation water. It is calculated value and is defined by the following equation (Wilcox, 1955) in which the concentrations are in meq/l.

$$
\% \mathrm{Na}=\frac{\left(\mathrm{Na}^{+}+\mathrm{K}^{+}\right) * 100}{\left(\mathrm{Ca}^{+2}+\mathrm{Mg}^{+2}+\mathrm{Na}^{+}+\mathrm{K}^{+}\right)}
$$

\begin{tabular}{cccc}
\hline$\% \mathrm{Na}$ & Water Class & \multicolumn{2}{c}{ Percentage of Samples } \\
& & Premon Season & Postmon Season \\
\hline$<20$ & Excellent & Nil & Nil \\
$20-40$ & Good & 6.4 & 5.5 \\
$40-60$ & Permissible & 37.6 & 51.4 \\
$60-80$ & Doubtful & 46.8 & 37.6 \\
$>80$ & Unsuitable & 9.2 & 5.5 \\
\hline
\end{tabular}

Table 3: Water class based on Sodium Percent (Wilcox 1955)

From Table 3 it was found that only $6.4 \%$ and $5.5 \%$ samples were suitable for irrigation in premonsoon and postmonsoon season respectively. While $93.6 \%$ and $94.5 \%$ were permissible to doubtful for premonsoon and postmonsoon season respectively. EC and \% $\mathrm{Na}$ are plotted in Figure 2. Which showed that most of the groundwater samples are not suitable for Irrigation.

\subsection{Residual Sodium Carbonate (RSC)}

Water quality for irrigation is influenced when concentration of carbonates and bicarbonates is higher than calcium and Magnesium. Waters containing high concentrations of these ions, calcium and possibly magnesium $\left(\mathrm{Mg}^{+2}\right)$ may precipitate as carbonates when water is concentrated by transpiration and evaporation. With the removal of calcium and magnesium from soil solution, the relative proportion of sodium is increased with attendant increase in alkali hazard. The residual sodium carbonate is is a measure of the hazard involved in the use of high carbonate waters. RSC is calculated as follows.

$$
\mathrm{RSC}=\left(\mathrm{CO}_{3}^{-2}+\mathrm{HCO}_{3}^{-}\right)-\left(\mathrm{Ca}^{+2}+\mathrm{Mg}^{+2}\right)
$$

Where all quality parameters (ionic concentrations) are expressed in milliequivalents per litre.

According to USDA (United State Department of Agriculture) waters with more than 2.5meq/1 RSC are not suitable for irrigation purpose. Waters containing $1.25 \mathrm{meq} / 1$ to $2.5 \mathrm{meq} / 1$ are marginal and those containing less than $1.25 \mathrm{meq} / \mathrm{l}$ RSC are probably safe. RSC (Residual Sodium Carbonate)values for $64.2 \%$ of the samples are low to medium where as $35.8 \%$ sample show high to very high RSC for premonsoon season and $82.60 \%$ of the samples are low to medium where as $17.4 \%$ sample show high to very high RSC for post-monsoon season. 


\subsection{Sodium Adsorption Ratio (SAR)}

SAR (Sodium Adsorption Ratio) is a measure of suitability of water for irrigation with respect to the sodium hazard. As higher deposition of sodium may cause damage to soil, soil irrigation with high sodium depositing waters are not suitable. SAR is directly related to adsorption of sodium by soil, therefore it is a better measure of sodium (alkali) hazard in irrigation water. Soil Permeability is reduced by much higher sodium content relative to calcium and magnesium. It inhibits the supply of water needed for crops (Ravikumar, P.,2011). The SAR values were calculated using equation,

$$
\mathrm{SAR}=\frac{\mathrm{Na}^{+}}{\left(\sqrt{\mathrm{Ca}^{+2}+\mathrm{Mg}^{+2}}\right) / 2}
$$

Where all ionic concentrations are expressed in milliequivalents per litre.

$68.8 \%$ of samples were found to be excellent, $22.9 \%$ good and $8.3 \%$ samples were found unsafe for pre-monsoon season. Whereas for post monsoon season $81.6 \%$ of samples were found to be excellent, $17.4 \%$ good and only 1 sample was found unsafe.

Based on salinity hazard water used for irrigation can be classified as C1, C2, C3 and C4 and S1, S2, S3 and S4 based on sodium hazard. Figure 3 shows plot of groundwater samples grouped on above basis.

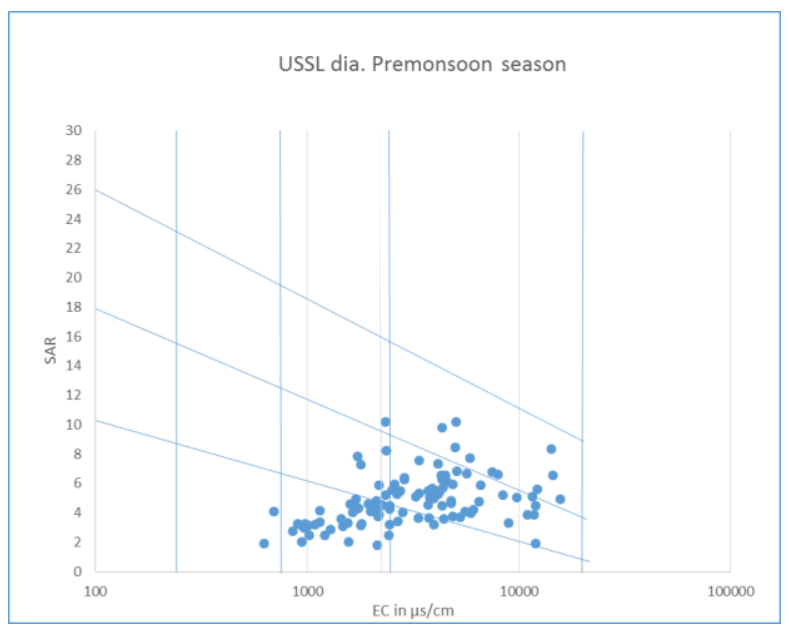

Figure 3: USSL dia. Premonsoon season

\subsection{Magnesium Hazard:}

In most waters Calcium and Magnesium maintain state of equilibrium. Calcium and Magnesium behaviour in soil is not equal in the soil system, and when waters are highly saline and Sodium dominated magnesium deteriorates soil structure. A high level of Magnesium is usually due to the presence of exchangeable Sodium in irrigated soil. Soil quality is adversely affected when more $\mathrm{Mg}^{+2}$ 
is present in water in equilibrium, rendering it alkaline, which results in decreased and adversely affected crop yields. MH for irrigation water was calculated using formula

$$
\mathrm{MH}=\frac{\mathrm{Mg}^{+2} * 100}{\left(\mathrm{Ca}^{+2}+\mathrm{Mg}^{+2}\right)}
$$

Soils become more alkaline and it adversely affect the crop yield for Magnesium hazard (MH) value of more than 50\%. MH values show only 1 sample fall in suitable category, while rest of samples fall in unsuitable category during pre-monsoon season. $9 \%$ samples fall in suitable category, while $91 \%$ fall in unsuitable category during post-monsoon season.

\subsection{Permeability Index:}

PI is another parameter based on which suitability of groundwater for irrigation is assessed. Soil permeability is also affected by prolonged use of irrigation water. It is influenced by $\mathrm{Na}^{+}, \mathrm{Ca}^{2+}, \mathrm{Mg}^{2+}$ and $\mathrm{HCO}_{3}^{-}$. PI was calculated using equation

$$
\mathrm{PI}=\frac{\left(\mathrm{Na}^{+}+\sqrt{\mathrm{HCO}_{3}^{-}}\right) * 100}{\left(\mathrm{Ca}^{+2}+\mathrm{Mg}^{+2}+\mathrm{Na}^{+}+\mathrm{K}^{+}\right)}
$$

The Permeability Index of study area varies from 30.3 - $101 \%$ for pre-monsoon season and 26.2-100.2\% for post-monsoon season.

\section{Conclusion}

Hydro geochemical analysis was carried out to understand process and mechanisms affecting groundwater for irrigation command area for open wells. The quality assessment was made using $\mathrm{pH}$, EC, Total Dissolved Solids, in addition major cations like $\left(\mathrm{Ca}^{+2}, \mathrm{Mg}^{+2}, \mathrm{Na}^{+}, \mathrm{K}^{+},\right)$and anions $\left(\mathrm{Cl}^{-}, \mathrm{SO}_{4}^{-}\right.$ ${ }^{2}, \mathrm{CO}_{3}^{-2}, \mathrm{HCO}_{3}^{-}, \mathrm{NO}_{3}^{-}$). Based on these analysis irrigation quality parameters like Salinity Index, \% $\mathrm{Na}$, SAR (Sodium Adsorption Ratio), MH (Magnesium hazard), Permeability Index (PI), RSC (Residual Sodium carbonate), and USDA (United States Department of Agriculture) classification. were calculated.

For Irrigation water quality parameter SAR (Sodium Adsorption Ratio) serves as a measure of suitability of water for irrigation with respect to the sodium hazard. High SAR values may cause damage to soil.68.8\% of samples were found to be excellent, $22.9 \%$ good and $8.3 \%$ samples were found unsafe for pre-monsoon season. Whereas for post monsoon season $81.6 \%$ of samples were found to be excellent, $17.4 \%$ good and only 1 sample was found unsafe. According to USSL diagram less than 25 $\%$ of samples for pre-monsoon \& post-monsoon season were found to be $\mathrm{C}_{3} \mathrm{~S}_{1}$ which indicates high salinity low sodium hazard. While rest were $\mathrm{C}_{3} \mathrm{~S}_{2} \& \mathrm{C}_{4} \mathrm{~S}_{3}$ which indicates high salinity high sodium hazard. The Permeability Index of study area varies from 30.3 - $101 \%$ for pre-monsoon season and 26.2-100.2\% for post-monsoon season. Residual Sodium Carbonate (RSC) values for $64.2 \%$ of the samples are low to medium where as $35.8 \%$ sample show high to very high RSC for pre-monsoon season and $82.60 \%$ of the samples are low to medium where as $17.4 \%$ sample show high to very high RSC for post-monsoon season.

Soils become more alkaline and it adversely affect the crop yield for Magnesium hazard $(\mathrm{MH})$ value of more than 50\%. MH values show only 1 sample fall in suitable category, while rest of samples fall in unsuitable category during pre-monsoon season. $9 \%$ samples fall in suitable category, while $91 \%$ fall in unsuitable category during post-monsoon season. Results of the study reveals that most of the 
groundwater samples were unsuitable for irrigation based on $\mathrm{MH}$. Groundwater quality in post monsoon season is good compared to premonsoon season, this may be because of recharge of aquifers.

\section{Acknowledgement}

The authors would like to thank State Water Data, Gandhinagar and Gujarat Engineering Research Institute (GERI), Vadodara for providing data for water quality parameters for carrying out this research work.

\section{References}

Brinda K. and Elango L. (2011). Hydrochemical characteristics of groundwater for domestic and irrigation purposes in Madhuranthakam, Tamilnadu, India, Earth Sci. Res. SJ. Vol. No. 2:101-108

Datta,P.S. and Tyagi,S.K.(1996). Major ion chemistry of groundwater in Delhi area: Chemical weathering processes and groundwater regime, Journal of the Geological Society of India, 47:179-188

Dawdy, D.R., and Feth, J.H. (1967). Applications of factor analysis in study of chemistry of groundwater quality, Mojave River Valley, California, Water Resources Research, 3:505-510.

Dhiman, S.D. (2014b). Groundwater Quality Assessment for Irrigation Use in Rajkot District, Gujarat" Journal of Indian Water Resources Society, Vol. 34, No. 1 pp 34-39

Elango,L., Kannan, R.,Senthil Kumar, M. (2003), Major ion chemistry and identification of hydrochemical processes of groundwater in a part of Kancheepuram district, Tamilnadu,India, Journal of Environmental Geoscience, 10:157-166

Hem, J.D. (1985). Study and interpretation of the chemical characteristics of natural water ( $3^{\text {rd }}$ ed.). U.S. Geological Survey Water Supply Paper, 2254,263

IS: 11624-1986, (Reaffirmed 2009) Guidelines for the quality of irrigation water, BIS, New Delhi.

Jeong, C.H. (2001). Effect of land use and urbanization on hydrochemistry and contamination of groundwater from Taejon area, Korea. Journal of Hydrology, 253:194-210.

Ravikumar, P., Somashekar, R.K. and Angami, M. (2011). Hydrogeochemistry and evaluation of groundwater suitability for irrigation and drinking purpose in the Markandeya River Basin, Belgam District, Karnataka State, India, Environ Monit. Assess. 173:459-487

Senthilkumar, M. and Elango L. (2013). Geochemical processes controlling the groundwater quality in lower Palar river basin, Southern India. J. Earth Syst. Sci.122, No.2:419-432

Sunderrajan K, Kumar S, Kampman D, Nagar A (2007) Groundwater and well-water quality in the alluvial aquifer of central Gujarat. A paper by Care water.

http://www.indiawaterportal.org/sites/indiawaterportal.org/files/Groundwater\%20Quality_Alluvi al\%20Aquifer_Central\%20Gujarat_CAREWATER_2007.pdf

Wilcox, L.V. (1955). Classification and use of Irrigation waters. Circular No. 969 United States Department of Agriculture Washington, D.C.

Zaprozec, A. (1972). Graphical interpretation of water quality data. Groundwater 10(2):32-43 